Tinbergen Institute Discussion Paper

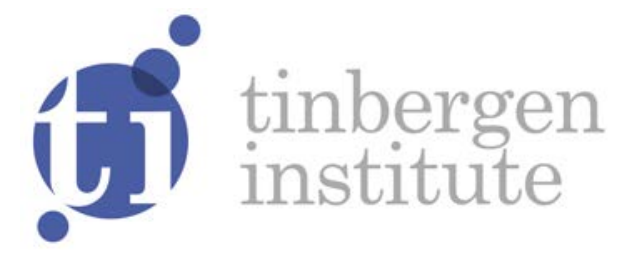

\title{
Entrepreneurial Choices of Initial Human Capital Endowments and New Venture Success
}

Vera Rochal

Mirjam van Praagl,2

Timothy B. Folta ${ }^{3}$

Anabela Carneiro 4

' Copenhagen Business School, Denmark;

2 Tinbergen Institute, the Netherlands;

3 University of Connecticut, United States;

${ }_{4}$ Universidade de Porto, Portugal. 
Tinbergen Institute is the graduate school and research institute in economics of Erasmus University Rotterdam, the University of Amsterdam and VU University Amsterdam.

More TI discussion papers can be downloaded at http://www.tinbergen.nl

Tinbergen Institute has two locations:

Tinbergen Institute Amsterdam

Gustav Mahlerplein 117

1082 MS Amsterdam

The Netherlands

Tel.: +31(0)20525 1600

Tinbergen Institute Rotterdam

Burg. Oudlaan 50

3062 PA Rotterdam

The Netherlands

Tel.: +31(0)10 4088900

Fax: +31(0)10 4089031 


\title{
Entrepreneurial Choices of Initial Human Capital Endowments and New Venture Success
}

\author{
Vera Rocha $\mathbf{1}^{\square}$ \\ Mirjam van Praag ${ }^{2}$ \\ Timothy B. Folta ${ }^{3}$ \\ Anabela Carneiro ${ }^{4}$
}

\begin{abstract}
The founder (team)'s human capital is a vital determinant of future firm performance. This is a stylized fact. Less is known about the effect of the human capital of the initial workforce hired by the founder(s). We study the performance consequences of a founder's choice of the initial workforce's human capital (quantity and quality), besides the human capital of the founder(s). The analysis is based on matched employer-employee data and covers about 5,300 startups in manufacturing industries founded by individuals coming from employment between 1992 and 2007. We acknowledge that initial hiring decisions are endogenous and correlated with the human capital of the founders and the ownership structure of startups (single founder versus team of founders). Given the stickiness of initial choices, human capital decisions at entry turn out to be a close to irreversible matter with significant implications for post-entry survival and growth of the firm.
\end{abstract}

Acknowledgements: The authors acknowledge GEE-MEE (Gabinete de Estratégia e Estudos Portuguese Ministry of Employment) for allowing the use of Quadros de Pessoal dataset.

\footnotetext{
$1 \bowtie$ Corresponding Author. vr.ino@cbs.dk. Copenhagen Business School, Department of Innovation and Organizational Economics. Kilevej 14A, DK-2000 Frederiksberg, Denmark. Phone: +45 38152563.

2 mvp.ino@cbs.dk, Copenhagen Business School, Department of Innovation and Organizational Economics \& Tinbergen Institute

3 timothy.folta@business.uconn.edu, University of Connecticut, School of Business

${ }^{4}$ anacar@fep.up.pt. Faculdade de Economia and CEF.UP, Universidade do Porto, Portugal
} 


\section{INTRODUCTION}

It has been argued that new ventures founded with larger and stronger endowments of human capital will perform better and survive longer. Such initial resources are believed to buffer the firm against misfortune (Bruderl and Schussler, 1990) or signal prospective investors about high potential (Cooper, Gimeno, and Woo, 1994; Shane and Stuart, 2002). Furthermore, these effects may have enduring consequences (Stinchcombe, 1965) because of positive feedback in the resource accumulation process in which initial advantages are amplified over time. ${ }^{1}$ Yet, theoretical and empirical research, so far, have treated initial human capital endowments as independent from other factors affecting performance or survival - which contrasts with the idea that initial human capital endowments represent a fundamental choice of the entrepreneur and are at least partly determined by her own qualities and capabilities, as well as by the qualities of the founded business. ${ }^{2}$ In this paper, we depart from prior research by considering that the quality and quantity of a venture's human capital endowments are not random, but simultaneously and endogenously selected by the entrepreneur, and by examining whether these choices are related to long term performance. A failure to account for the non-randomness of initial human capital composition risks over- or understating the true effect on performance.

Our treatment of the question regarding whether initial human capital decisions have enduring consequences differs from prior work in several respects. First, we adopt an empirical approach that addresses the self-selectivity and endogeneity issues completely ignored by previous literature. We recognize that founders choose initial human capital endowments, and that these choices are at least partially determined by attributes of the founder and type of venture. ${ }^{3}$ Moreover, these multiple choices

\footnotetext{
${ }^{1}$ Even if human capital resource stocks might be imitable (Coff, 1997), they may buffer the firm against shocks and/or create some initial advantage providing path dependent effects.

${ }^{2}$ A belief that initial human capital is independent of other variables causing performance or survival is akin to believing that it is exogenously determined.

${ }^{3}$ Though we are not the first to recognize this (see, for example, Colombo et al., 2004 and Hvide and Moen, 2010), we are the first to show how it affects performance. Relatedly, Mata and Machado (1996), Cabral and Mata (2003), and Agarwal and Audretsch (2001) have shown great heterogeneity in initial sizes of new ventures, and Haltiwanger et al. $(1999,2007)$ find evidence that workforce composition is also heterogeneous, even within narrowly defined industries, regions, and startup years.
} 
are simultaneous. The simultaneous self-selection of a venture's initial human capital endowments by founders poses challenges to the estimation of their effects. To deal with these challenges founderspecific benchmarks for human capital endowments are identified using a system of simultaneous equations in our first-stage analysis, where benchmarks represent expected endowments based on decisions of similar founders for similar firms. We then consider how firms' human capital endowments compare relative to their expected benchmarks and examine how deviations from founder-specific benchmarks relate to new venture performance in the second step. We believe this approach addresses the fact that human capital choices may be endogenous to performance. The performance consequences we examine include venture survival and firm-level employment growth. We discuss how this focus on a venture's relative human capital position at founding may be important to mitigate these empirical issues and demonstrate that our approach produces substantively different results compared to prior research.

A second difference is that prior research emphasizes how a venture's initial size (in terms of employment) affects its performance and survival (Bruderl and Schussler, 1990; Mata and Portugal, 1995; Audretsch et al., 1999; Aggarwal and Audretsch, 2001), whereas, much less work has focused on the impact of the quality of the venture's initial human capital. Exceptions include Eisenhardt and Schoonhoven (1990), who show that ventures with stronger founding teams grow faster, and Shane and Stuart (2002), who find that founding team startup experience increases the rate of venture capital funding. Most studies place emphasis on the founder's human capital, and entirely ignore the human capital of employees outside the founding team. To the best of our knowledge, Eisenhardt and Schoonhoven (1990) is the only other study analyzing the relationship between both human capital quantity and quality decisions at entry and performance (in terms of organizational growth). No prior work has considered venture performance implications of a venture's initial workforce and founder(s)' initial quality, while acknowledging their correlation that may bias the estimated effects on business performance.

A third difference is that all prior research in this realm focuses on easily observed qualities of the venture founder or team, such as education, experience, age, earnings, or gender. It may be that the most 
important characteristics of the entrepreneurial team are not easily observable, but are represented by innate abilities or informal skills, such as passion, energy, or listening and communication skills. We account for both observed and unobserved skills of the initial workers and founders through a single measure of human capital quality that was developed by Portela (2001), but has not been previously employed in entrepreneurship research. The unobserved skills included in our analyses are the ones that determine earnings premia in the labor market. Estimating founder-specific benchmarks that incorporate both observed and unobserved factors minimizes the likelihood that the drivers of human capital choices are determined by unmeasured factors that also determine new venture success. This strengthens our strategy to deal with self-selectivity and endogeneity in entrepreneurs' human capital choices at entry.

A final difference is that we consider how founder motivations may dictate the importance of initial human capital decisions. We distinguish between two types of ventures - those formed through necessity, where founders had been pushed from employment due to some negative event; and those formed to take advantage of an opportunity. Our results suggest that initial human capital decisions have more enduring impact for opportunity-driven ventures. Prior research is silent on this issue because it has neglected this kind of heterogeneity. A likely reason for this gap is the lack of available entrepreneurship data matching information on (different) founders, their firms, and the workers they hire.

Our study is based on a matched employer-employee dataset for Portugal, and covers about 5,300 startups founded by individuals coming from employment and entering manufacturing industries during the period 1992-2007. The data source has been used previously to study new venture dynamics (e.g., Mata and Portugal, 1994; Cabral and Mata, 2003; Geroski, Mata, and Portugal, 2010; Rocha et al., 2015). Our empirical evidence supports the notion that a venture's initial human capital endowment has enduring performance consequences, but differently than how prior research has documented. We also find that relative size and strength of human capital have different effects: ventures starting at a smaller size than benchmarks suffer a significant survival penalty, while those starting with stronger human capital than benchmarks tend to grow more rapidly. These findings have strong implications for how we interpret prior research. 


\section{EMPIRICAL APPROACH}

\subsection{Contributions based on the empirical approach}

We study the (causal) relationship between initial human capital choices and business performance and use a methodology that has the following characteristics (to be discussed more extensively in later subsections). First, we consider multiple choices with respect to the employment of human capital in tandem in a system of equations. We include into this system choices around the initial stock of human capital: the choice to start in a team or not, the number of employees, the quality level of the founder(s), and the choice of quality level of non-founder employees. The system we estimate allows all these decisions to be interrelated and determined by the (unobserved) characteristics of the founder. With this approach we take into account that, for instance, more capable founders may be able to attract more and better employees. Indeed, research shows that initial employment size is determined by factors such as work experience, education, entrepreneurial experience, and founder wealth (Colombo et al., 2004; Hvide and Moen, 2010; Coad et al., 2014; Mellilo, Folta, and Delmar, 2014), and that more skilled entrepreneurs are more likely to attract more skilled workers (e.g., Baptista et al., 2013). Our approach addresses the issue of self-selectivity of entrepreneurs into certain human capital choices at startup, by using a skill index that is also based on unobserved "earning power", as well as through the error terms structure of the system of equations.

Second, based on the predicted values of all relevant dimensions of human capital included in this system, we estimate founder-specific benchmarks that consider both (observable and unobservable) founder and firm characteristics (such as industry). We next compute deviations from these individual benchmarks for each new venture and relate them to multiple performance measures in the second stage. Our motivation to consider these relative positions rather than absolute positions is as follows. Logically, it makes little sense to compare the effect of initial hiring decisions on the survival chances of an oil company to those of a software company. Accordingly, some scholars recognize that an emphasis on absolute human capital (e.g., employment size) may mask important differences across industries, and so they consider firm positions relative to some industry benchmark (Dunne et al., 1988; Mata and Portugal, 
1994; Audretsch et al., 1999, 2000, 2001; Geroski et al., 2010). However, this approach does not adequately consider that factors such as founder's ability and experience may co-determine the relationship between human capital and performance. Thus, the effect of initial human capital stocks on performance can better be measured by comparing the effect of human capital choices on performance within a micro cosmos of comparable firms and founders. This approach, analogous to propensity score matching, but based on both observed and unobserved qualities of the founder (due to the skill measure we use) addresses the issue that human capital choices are endogenous in the performance equations to some extent.

The extent to which endogeneity issues are solved by using relative positions compared to a narrowly defined benchmark hinges on the validity of the assumption that deviations from the founderspecific benchmarks are not determined by the same factors that determine performance outcomes. Entrepreneurs starting up with higher quantity or quality of human capital than the average narrow set of comparable firms may do so out of ignorance, due to forecasting errors, over-optimism, overconfidence, or, for instance, risk seeking (Camerer and Lovallo, 1999; Bolger et al., 2008; Åstebro et al., 2014; Hyytinen et al., 2014). On the other hand, those who do not reach the size and/or quality thresholds are more likely to correspond to financially constrained (Cabral and Mata, 2003), pessimistic, or risk averse entrepreneurs. Other explanations for the existence of many startups entering at sub-optimal scales include the entrepreneurs' expectations of learning by doing (Jovanovic, 1982; Pakes and Ericson, 1998). Many entrepreneurs are actually uncertain about their ability and efficiency, so they may decide to enter at a very small scale, relying on the expectation that they will be able to correct their entry decision later on and grow, as they update their beliefs about their ability and efficiency (Audretsch and Acs, 1990; Audretsch et al., 1999, 2000). All these reasons to deviate from the estimated benchmark may be unrelated to the determinants of performance. However, we acknowledge that some startups may deliberately deviate from the benchmark because they have private information on why doing so would benefit their companies. We acknowledge that this kind of endogeneity is not addressed by our approach and may cause a remaining bias. 
The consequences of deviating from the benchmark quantity and quality of human capital at the time of entry may be, however, quite persistent. Initial positions may be sticky and hard to correct over time, either due to firm structural inertia (Gilbert, 2005), labor market rigidities and consequent adjustment costs (Hamermesh and Pfann, 1996), or entrepreneurs' long-lasting limitations in terms of talent and/or financial liquidity (Colombo and Delmastro, 2002; Cabral and Mata, 2003; Agarwal et al., 2009). Even if some adjustments in initial hiring decisions can be made later on, startup conditions may become imprinted in the firm and have even enduring effects on firm success (e.g., Geroski et al., 2010).

All in all, using relative positions instead of absolute positions, and acknowledging that the relevant human capital choices under study are simultaneous and inter-related with other factors, is a way of addressing the self-selection and endogeneity issues so far overlooked by prior research. The skill index we use to measure entrepreneurs' and workers' quality and the econometric strategy adopted in the estimation of founder-specific benchmarks are fundamental in that regard. We discuss them below, after briefly describing our dataset.

\subsection{Data and Sample}

Our data come from Quadros de Pessoal (hereafter, QP), a large longitudinal linked employeremployee dataset collected by the Portuguese Ministry of Employment. A primary benefit of using QP to address our research question is that it covers all private firms operating in Portugal (and employing at least one wage earner), which contrasts with data that may systematically ignore smaller ventures. Available information at the firm-level includes employment, sales, industry, ownership, location, among others. At the individual-level, QP reports information about each worker's age, education, gender, qualifications, wages, occupational category, tenure, number of hours worked, and type of contract. All firms, establishments and workers are identified with a unique identification number, so they can be followed and matched over time. Raw QP files are available for the period 1986-2009.

Entries of new firms are identified by the first year a firm is recorded in QP files, and founders are identified by their listing as "employers". Our analysis is based on startup firms entering in year $t$ in 
manufacturing industries, whose founder(s) was (were) in paid employment in $t-1$ or $t-2$. We furthermore distinguish between startups founded by individuals who left their job in $t-1$ or $t-2$ in a firm that either closed down or suffered a massive downsizing (larger or equal to $30 \%$, with a minimum of five displacements) in the same year, and those whose previous employer remained in operation after the exit of the employee(s), without suffering any considerable downsizing. While this latter group of startups may be closer to opportunity-driven entrepreneurship, the former might have been founded for necessity reasons (i.e., involuntary displacement and consequent job loss). We exclude startups when any founder was unobserved in the QP files prior to founding, because we cannot ascertain whether their absence is correlated with the human capital choices they made at founding.

Our final sample is composed of all the startup firms entering manufacturing industries between 1992 and 2007 (excluding 2001), employing at least one wage earner at the moment of startup, and for which we can identify the founder(s), who came from paid employment. ${ }^{4}$ Data for the years 1986-1991 were only used to trace and characterize the experience of these founders in the labor market. A total of 5,341 startup firms with complete information on the key variables of interest fulfill these conditions. About $62 \%$ of these firms are founded by a single entrepreneur (instead of a team of two or more), and $44 \%$ are established immediately after the closure or massive downsizing of the previous employer (whom we refer to as necessity-driven entrepreneurs).

We analyze the survival and employment growth of these firms until the end of the observation period or until the moment of an eventual ownership change (depending on which of the options occurs first). ${ }^{5}$ The analysis stops in 2007 , the last year for which we can accurately identify the exit of firms. Firm

\footnotetext{
${ }^{4}$ There is a gap for the particular years of 1990 and 2001 in the worker-level files, for which no information was gathered at the individual-level. For this reason, our analysis focuses on startups founded in 1992 or later, excluding those founded in 2001 due to the missing data at the worker-level for that year, which does not allow us to accurately identify the founder(s).

${ }^{5}$ About $42 \%$ of the firms in our sample suffer changes in the entrepreneurial founding team over their lifecycle. After ownership changes, the business identity may be no longer the same, as the entrepreneur-firm quality match may also change. It is not however our aim in this paper to study what explains these processes of ownership change, neither their impacts. For this reason, we censor the spells at the point of ownership change. We conduct robustness checks to confirm that our results are not affected by this procedure.
} 
exit is identified by the moment when a firm ceases to answer the survey. ${ }^{6}$ Following previous studies using QP dataset to study firm exit (e.g., Mata and Portugal, 2002; Geroski et al., 2010), we require an absence of the firm from the files larger or equal to two years in order to identify its definite exit. For this reason, data for 2008 and 2009 are only used to check the presence or absence of firms in QP files.

\subsection{Measuring Human Capital Quality}

We measure two types of human capital quality: quality pertaining to founders and quality pertaining to non-founder venture employees. Previous work recognizes that measuring human capital quality is challenging (Iranzo et al., 2008). Existing studies construct human capital proxies using observed dimensions, such as workers' educational attainment, age, earnings, or gender (e.g., Haltiwanger et al., 1999, 2007; Ilmakunnas et al., 2004), an approach disregarding unobserved capability, which might include skills that are innate or derive from informal experiences (see also Iranzo et al, 2008; Martins, 2008). This disregard is especially problematic since Abowd et al. (1999) show that observed levels of workers' skill heterogeneity imperfectly reflect the true level of heterogeneity. Our measures of a venture's human capital incorporate two observed dimensions (i.e., education and experience) and a third dimension capturing unobserved components of human capital quality that determine earnings in the labor market.

The starting point for our venture-based measures is to create a skill index for each individual associated with a venture, either as a founder or as an employee. To do so, we use the multi-dimensional skill index developed by Portela (2001), which is intuitively appealing and flexible enough to account for many components of human capital, and incorporates unobserved dimensions of human capital. ${ }^{7}$

\footnotetext{
${ }^{6}$ We define exit as firm closure. Despite the comprehensiveness of QP dataset, it does not allow the distinction between different modes of exit. Regarding the exits due to mergers or acquisitions (M\&A), prior studies (e.g., Geroski et al., 2010) have documented that less than $1 \%$ of the total number of liquidations in Portugal has been due to M\&A, thus suggesting that our inability to identify mergers in QP is not likely to affect our results.

${ }^{7}$ This multi-dimensional skill index has also inspired other authors to construct new and better quality measures in other contexts. Sá et al. $(2004,2012)$ use a similar index inspired on Portela's skill index to construct a composite
} 
Appendix A details the derivation of each individual's skill index. After computing the skill index for each individual $i$ in each firm $j$ and year $t$, we can calculate our two measures of human capital quality. Initial Workforce Quality is the average skill index of the workers hired at entry by firm $j$, and Initial Founder Quality is the average skill index of the founder(s) at entry. ${ }^{8}$ The interpretation of this skill measure is intuitive and is based on the average education level of workers and entrepreneurs, and then adjusted to take individuals' experience levels and (unobserved) permanent skills that determine earnings premia into account.

\subsection{Estimating How Ventures Deviate from Human Capital Benchmarks}

Human capital benchmarks for quality and quantity are estimated for each venture in a way that accounts for the simultaneity and inter-relatedness between human capital decisions. Our approach is identical to Roodman's (2011), which extends the logic of seemingly unrelated regression models while allowing the consistent and efficient estimation of fully observed recursive equation systems. It also has the advantage of enabling the estimation of a panoply of models (e.g., probit models, linear regressions, truncated regressions) within the same system of equations. The system of equations we estimate is described in Appendix B and includes the following dependent variables: (a) human capital quality pertaining to the founding team; (b) human capital quality pertaining to all other venture employees; (c) the venture's number of employees; and (d) the decision to start alone or with partners.

The estimation of this system of equations enables a computation of relative human capital quality and quantity for each venture. This computation proceeds in two steps. First, the estimation is used to predict the quantity and quality of human capital to be employed at the moment of entry. Then we

measure of universities' education quality in The Netherlands. This index allows them to take into account different university attributes, as well as the relative position of each university in each attribute.

${ }^{8}$ Given that the person-specific effect is estimated based on individuals' spells in wage employment, the average skill index of the founders was only possible to compute for those entrepreneurs with a record of at least two years in paid employment. 
measure the extent to which each venture's human capital quality and quantity deviate from their predicted benchmarks, and divide that value by the predicted benchmark, as shown below:

$$
\begin{aligned}
& \text { Size Deviation }=\frac{\text { Initial Venture Size }- \text { Benchmark Size }}{\text { Benchmark Size }} \\
& \text { Worker Quality Deviation }=\frac{\text { Initial Workforce Quality }- \text { Benchmark Workforce Quality }}{\text { Benchmark Workforce Quality }}
\end{aligned}
$$

Worker Quality Deviation focuses on the average quality of all non-founder employees. Similarly, Size Deviation pertains to all the paid employees hired, excluding the founder(s). Our two measures of interest are thus defined as the initial human capital workforce quality and quantity relative to comparable firms with similar entrepreneurs, driven by factors (largely) not related to performance. We claim that using these measures alleviates biases when estimating their effects on venture performance by reducing endogeneity and self-selection issues.

\section{INITIAL HUMAN CAPITAL AND ITS IMPACT ON VENTURE SUCCESS}

\subsection{Descriptive Analysis}

Table 1 summarizes the average workforce quantity as measured in the number of venture employees, the average workforce quality as described in section 2.3, and the deviations from human capital benchmarks as described in section 2.4. On average, firms have around seven employees at entry. The average venture that is started up is smaller than its benchmark size, which is possible because benchmarks are derived from a sample including new and established firms, as described in Appendix B. Actually, deviating from the benchmark size appears to be a common phenomenon in our sample, as only $8 \%$ of the startups enter at a scale close to the benchmark (absolute deviations below $10 \%$ of the benchmark). Most firms (69\% of the sample) enter smaller and about $37 \%$ of startups deviate by more than $50 \%$ below the predicted entry size. The remaining $23 \%$ of our sample enters above the benchmark, with $13 \%$ of the firms entering with a workforce size over $50 \%$ above the benchmark. Compared to firms that fail, surviving firms start larger, have higher workforce quality, and have a smaller negative deviation from benchmark size (Table 1). 
Figure 1 illustrates how deviations from benchmarks change over the life of ventures that survive at least five years, where Panel A considers deviations in size, whereas Panel B shows deviations in the workforce quality. The five separate lines in each panel correspond to ventures (a) at least $50 \%$ below their benchmarks; (b) 10-50\% below their benchmarks; (c) $10 \%$ below to $10 \%$ above their benchmarks; (d) $10-50 \%$ above their benchmarks; and (e) over $50 \%$ above their benchmarks. Both panels show some convergence, meaning that deviations from benchmarks tend to get smaller over time. Nevertheless, the key takeaway from Figure 1 is the persistence of deviations, implying that human capital decisions at founding seem to be "sticky" and have enduring consequences. Firms entering with higher (lower) levels in terms of quantity and quality of human capital relative to very similar competitors persist with higher (lower) levels some years later. This appears to be particularly true for workforce size, which shows very little convergence. Convergence tends to be stronger for worker quality.

[Insert Table 1 and Figure 1]

\subsection{Initial Human Capital Choices and Venture Hazard}

The descriptive evidence presented above suggests that there may be important survival implications when initial human capital decisions deviate from similar firms with similar founders. We test whether the relationship holds in a multivariate model estimated with a semi-parametric discrete time proportional hazard model. ${ }^{9}$ A major advantage of hazard-rate models for the analysis of duration data is

\footnotetext{
${ }^{9}$ This approach avoids mis-specifying the baseline hazard function. Unobserved heterogeneity at the founder level is taken into account by incorporating in the hazard equation a Gamma-distributed multiplicative term, with unit mean and finite variance $\sigma_{v}^{2}$ (Lancaster, 1990). Formally, the hazard rate of each firm $i$ exiting at discrete time $t_{j}, j=$ $1,2, \ldots$, given survival until then, may be written as follows:

$$
h_{i j}=1-\exp \left\{-\exp \left[\gamma(t)+X_{i}(t) \beta+\log \left(\varepsilon_{i}\right)\right]\right\}
$$

where $\gamma(t)$ is a set of indicator variables for different duration intervals, thus flexibly describing the pattern of duration dependence in hazard rates, $X_{i}(t)$ is a vector of variables that are expected to be associated with firm survival, $\beta$ is a vector of unknown parameters to be estimated, and $\varepsilon_{i}$ is the Gamma-distributed random term describing founder unobserved permanent heterogeneity. Vector $X$ includes the key variables of interest - i.e., deviations from estimated benchmarks for human capital quantity and quality - as well as a number of controls that may also influence firm survival, namely founders' quality and specific human capital measures, firm location in urban regions, and a set of industry variables that are typically included in firm survival studies (concentration, minimum efficient scale, industry employment growth rate, industry agglomeration, and entry rates) (e.g., Mata and Portugal, 2002; Geroski et al., 2010).
} 
their capacity to deal with right-censored data, which is the case when firms continue to survive beyond the observation period (i.e., 2007). Table 2 illustrates our results. Positive coefficients reflect a positive association with the hazard of the firm. All models include a spectrum of control variables, including those related to the founder.

Column (1) introduces a set of variables related to founders' general and specific human capital and the ownership structure at entry (single founder vs. team of founders). The results show that founders with higher human capital quality and with longer industry experience have ventures with lower hazard rates. Also, founding a startup alone increases the exit risk relative to sharing the ownership. These founder effects, that are robust across all specifications in Table 2, are consistent with earlier studies (Bates, 1990; Delmar and Shane, 2006). This is noteworthy because in our case they have been estimated in a more complete model including workforce quality and unobserved skill components of both founder(s) and employees. Moreover we include both solo and team startups and acknowledge that starting up with teams (or solo) and certain numbers of employees with specific levels of qualities are (simultaneous) choices made by the founder(s).

Column (2) reports the effect of initial size. Consistent with prior research (e.g., Brüderl et al., 1992; Audretsch and Mahmood, 1994; Mata and Portugal, 1994), starting ventures with more employees reduces firm hazard. Our result therefore shows that earlier findings were not (completely) driven by the fact that, for instance, smarter founders start up firms with more employees.

Column (3) reports the effects of workforce quality, which has been ignored in prior research. We find that higher average workforce skill levels at entry are associated with a lower hazard rate in new firms. It is noteworthy that worker quality effects are important even in the presence of a variable for founder quality. This implies that worker skills are an important complement to founder skills in predicting new venture survival. It is also noteworthy that founder quality continues to have a strong effect on survival, albeit a smaller effect than reported in models (1) and (2).

Columns (4) and (5) introduce deviations from human capital benchmarks. These are fundamental variables in our study because they provide added assurance that our predictions are not burdened by 
endogeneity (as long as the benchmark includes all factors that drive decisions about workforce size and quality that are related to performance). Likelihood ratio tests confirm that neither model is a significant improvement over model (3). However, when we bifurcate our deviations above and below their benchmarks we get substantively different results.

We show in columns (6) and (7) that bifurcating positive and negative deviations around the benchmark are preferred to the single measures used in columns (4) and (5). This suggests that initial human capital choices above and below benchmarks have asymmetric effects. A Likelihood Ratio test confirms that model (6) provides a significantly stronger fit with the data than model (4), which suggests that consideration of asymmetric size deviations is important to understanding firm survival. An examination of the coefficients suggests three interesting results.

First, the inclusion of bifurcated size deviations eliminates the impact that Startup Initial Size has on survival. This is extremely noteworthy since prior research has emphasized initial size as fundamental to survival. Second, firms starting at a smaller size than benchmarks have higher hazard rates. According to the estimations reported in column (7), entering with a startup size $30 \%$ smaller than similar firms with similar owners increases the exit risk by $25 \%$. This evidence is consistent with the explanation that firms starting relatively small are at a competitive disadvantage. Since survival differences for firms starting larger than benchmark firms are less significant and relatively marginal in magnitude, the results suggest an asymmetry in the relationship between survival and positive and negative deviations from the benchmark startup size. Third, worker quality deviations do not seem to be associated with survival, since a Likelihood Ratio test suggests that the addition of the workforce quality deviations in Model (7) is not a significant improvement over model (6). Accordingly, it seems that exogenous changes in worker quality (represented by the workforce quality deviations) are less relevant than deliberate changes in human capital quality levels that are associated with performance perspectives (which are included in the absolute measures for workforce quality).

Model (8) introduces a dummy variable for whether the founder was necessity-driven or opportunity-driven, and a Likelihood Ratio test confirms that this model does not provide a significant 
improvement over model (7). Nevertheless, in the last two columns of Table 2 we separate the sample into necessity-driven and opportunity-driven ventures to try to ascertain whether human capital decisions have the same effect across these two types of ventures. A Likelihood Ratio test confirms a significant improvement in fit relative to model (7). It seems that opportunity-driven ventures have a greater survival penalty when starting smaller than benchmark firms. For this group of entrepreneurs, a negative deviation of $30 \%$ from the expected startup size is associated with an increase in the exit risk of $35 \%$ (compared to $16 \%$ for necessity entrepreneurs). These results suggest that it may be important to distinguish entrepreneurs according to their motivation to enter the market.

Our results are robust to a number of alternative model specifications. Following Gimeno et al. (2010), we additionally controlled for changes in size and average quality level since founding. This helps us ascertain whether initial human capital still matter once we control for eventual adjustments made in the workforce over firm lifecycle. Our results for size deviations remain consistent, which confirms that even though firms might slightly adjust their initial human capital endowments afterwards, the initial positions in size have a long-term effect on survival. Furthermore, we tested alternative specification experimenting with various transformations of our key independent variables (e.g., logarithmic transformations and including higher powers of the same variables). We also used alternative measures of workforce size and quality deviations, merely taking the difference between actual and predicted values. With these efforts we saw very little difference in the results presented. As a final robustness check, we repeated our estimations for the subsample of startups that never experienced an ownership transfer during the period under analysis, and for the global sample of startups in manufacturing but without imposing the right-censoring at the point of ownership change (i.e., also including the spells under the ownership of a new entrepreneur or a new team). The results (not reported but available upon request) remained qualitatively unchanged in all these cases.

[Insert Table 2] 


\subsection{Initial Human Capital Choices and Firm-level Employment Growth}

In this section, we attempt to go beyond survival and explore how initial human capital choices are related to firm-level employment growth. For this purpose, we estimate comparable regressions for employment growth, always comparing the adjustments made in the firms' workforce between year $t$ and $t+1$. Since employment growth rates are only observed for firms surviving between $t$ and $t+1$, a twoequation Heckman model is estimated to account for survival bias. ${ }^{10}$ Table 3 reports the results for the second stage.

\section{[Insert Table 3]}

In line with the results found for firm survival, we find that ventures founded by more skilled entrepreneurs, with longer experience in the industry, and longer experience in management positions, achieve higher employment rates. This is consistent with prior literature using alternative growth measures (e.g., Eisenhardt and Schoonhoven (1990) for sales growth). The results also indicate that single founders grow less than teams, on average.

Regarding the initial quantity and quality of employee human capital, workforce quality seems to have a more robust effect on growth than workforce size. Firms starting with an average employee quality level below (above) benchmark firms have lower (higher) growth rates. The growth penalty of starting below the benchmark quality level seems to be greater than the benefit of starting above the benchmark. From column (8) we estimate that ventures hiring an initial workforce with an average quality level $30 \%$ higher (lower) than the benchmark will grow about 10 percentage points more (6.5 p.p. less) than firms not deviating from the benchmark, everything else constant. Though necessity-driven entrepreneurial ventures grow less than their opportunity-driven counterparts, the latter seem to be more strongly affected by the quality of the workers they choose to hire at entry.

\footnotetext{
${ }^{10}$ The Heckman two-step procedure has been used by several recent studies on the relationship between firm growth and survival (e.g., Delmar et al., 2013; Koch et al., 2013; Huber et al., 2014).
} 


\section{DISCUSSION}

An assumption about the importance of human capital in venture success is entrenched in social science, yet prior work has implicitly assumed that human capital decisions are independent from founder characteristics and the type of venture founded. This assumption implies that the founder has no role in formulating an initial strategy around human capital quality and quantity. Such assumptions are risky because they not only mischaracterize entrepreneurial practice, but also because they may misrepresent the true effects of initial human capital quality and quantity. Our empirical approach goes beyond prior research to correct this assumption, and measures to what extent (exogenous) changes in human capital quality and quantity are associated with firm survival and growth, while accounting for the fact that human capital decisions are interrelated. We do so by using a two stage model where human capital choices are compared to narrow benchmarks that are jointly estimated, consisting of similar firm-founder combinations. Our longitudinal study of Portuguese firms enables us to construct benchmarks of venture size and workforce quality of comparable firms started by comparable founders, an important step in the process of explaining the effect of human capital decisions on venture performance. In the second stage, these (benchmarked) human capital choices are related to firm performance in terms of survival and growth. Our paper has three broad implications for research on entrepreneurship.

First, earlier results on the association between founder (team) human capital and long-term firm performance are resonated in our study: team ventures perform better than solo ventures and firm performance benefits from entrepreneurs having higher levels of skills, industry, and management experience, both in terms of survival and firm growth. In other words, firm performance benefits from the quantity and quality of human capital in the founding team. These results are consistent with prior studies

(e.g., Bates, 1990; Eisenhardt and Schoonhoven, 1990; Cooper et al., 1994; Colombo and Grilli, 2005) and are obtained while using an improved specification (in two stages) accounting for various other human capital choices that entrepreneurs make simultaneously at the startup of their firm. The effects are not only statistically significant, but they are, in fact, rather sizeable: according to our estimations (global 
specifications for all sample), when founders' quality level increases by one standard deviation, firm hazard is estimated to be $10 \%$ lower and firm-level employment growth is 4 percentage points higher on average.

Most importantly, besides the effect of the quality and quantity of the human capital of the founder(s), the initial human capital choices embedded in the workforce have strong performance effects too. Taking into account that entrepreneurs design their workforce based on their own (team) characteristics and that their choices for a team, workforce quality, and quantity are made simultaneously, we find the following consistent results.

Our second main conclusion is that the initial size of the workforce in a venture (relative to comparable founder-firm combinations) has important implications for survival. Moreover, the effects persist even when accounting for the fact that firms might adjust their initial choices over the lifecycle. This result is consistent with earlier research that has diagnosed a strong and persistent effect of initial venture size without controlling for endogeneity (e.g., Geroski et al., 2010). Interestingly, our results suggest that the effect of initial firm size is asymmetric. Starting with fewer employees than benchmark firms imposes a strong survival penalty, but starting with more employees does not offer a survival premium. Our additional results indicate that initial firm size, again measured in terms of the deviation from the benchmark, has little impact on firm growth. ${ }^{11}$

Third, we find that workforce quality (deviations) has a strong effect on venture growth but not on survival (when controlling for the absolute level of workforce quality). This complements the more wellknown result based on a relatively small set of empirical studies - including ours - having found that founding team quality influences venture performance. Our results show that the human capital beyond the founding team is also quite important. It is particularly noteworthy that workforce quality effects

\footnotetext{
${ }^{11}$ Most research on the relationship between firm size and growth has looked at the effect of current size instead of startup size, with the intention to test the so-called Gibrat's Law - also known as the law of proportionate effect, according to which the proportional rate of growth of a firm is independent of its absolute size. Their evidence often suggests that this premise fails to hold (e.g., Audretsch et al., 1999). To the best of our knowledge, no other study has looked at the effects of initial size acknowledging the self-selection and endogeneity issues involved and previously discussed.
} 
persist in the presence of founding team quality effects. The asymmetry we observe for the effect of initial size on firm survival is weaker in the case of workforce quality: both positive and negative deviations from the benchmark are found to have significant effects on firm growth, though the effects might be more sizeable in case of negative deviations.

Although we believe we have used a unique data set to explore the complex relationship between initial human capital and venture performance, there are some limitations. Different data might allow to better account for observable measures of worker quality. We were constrained by the availability of continuous measures of individuals' human capital. We overcame this limitation by estimating an unobserved component of skill based on the fixed "earnings premia" of individuals in their past careers, which has not been used in prior entrepreneurship research, but has been proposed in other research fields (e.g., Iranzo et al., 2008).

Second, the "unobserved" part of our skill measure is based on fixed effects from employees' wage equations. So if a person has often earned more (less) than can be justified based on her observed skills, the unobserved skill component is positive (negative). Thus, the measure is not directly based on specific skills that are possibly productive in these startups.

A third limitation of this study is that we have not completely solved the problem that workforce choices are endogenous in firm performance equations. Although we have argued that the deviations we measure could reasonably be interpreted as exogenous shocks in the size and quality of the workforce, there will still be cases in which this interpretation is not valid. Entrepreneurs may have deliberate reasons to deviate from a closely defined benchmark based on private information or unobserved constraints that are not explained by their observed characteristics. Nevertheless, we can still safely claim that our approach mitigates important drawbacks of earlier studies thereby leading to more precise estimates of the causal impact of an entrepreneur's choices related to their workforce on long-term firm performance. 


\section{APPENDIX A}

\section{Details of Derivation of Individual Skill Indices as a Measure of Human Capital Quality}

The skill index $S$ of each individual $i$ in each year $t$ is computed as follows:

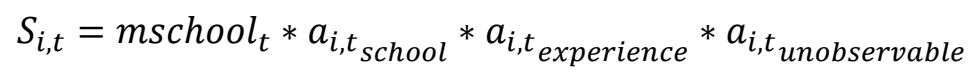

where, for each year $t$, mschool is the average schooling years in the economy; $a_{i_{\text {school }}}$ is a correction factor taking into account the actual position of individual $i$ in the schooling distribution; $a_{i_{\text {experience }}}$ is a correction factor taking into account the position of individual $i$ in the distribution of experience; and $a_{\text {unobservable }}$ is a correction factor taking into account the position of individual $i$ in the distribution of unobserved quality. ${ }^{12}$ The choice to multiply components is justified because the factors complement each other.

The factor correcting the schooling level of individual $i$ is measured as

$$
a_{i_{\text {school }}}=0.5+\frac{e^{\left(\text {school }_{i}-\text { mschool }\right) / \text { sschool }}}{1+e^{\left(\text {school }_{i}-\text { mschool }\right) / \text { sschool }}}
$$

where $s_{\text {chool }}$ is the schooling level (in years) of worker $i$ and sschool represents the standard deviation of schooling in the population. ${ }^{13}$ Bound between 0.5 and 1.5, this correction factor takes on values larger (smaller) than 1.0 when individuals are more (less) educated than the average person. So, the corrected schooling level, mschool $* a_{i_{\text {school }}}$, represents the base skill of individual $i$ obtained by standardizing the relative position of the worker in the schooling distribution.

The next component of the skill index corrects for experience, and is measured as

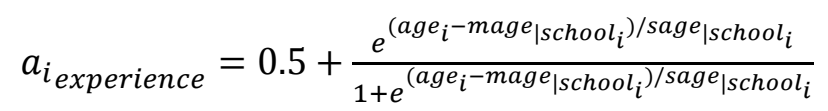

where $a g e_{i}$ is the age (in years) of worker $i$, mage $_{\mid s c h o o l}$ is the average age within schooling level $\operatorname{school}_{i}$, and sage $_{\mid s c h o o l}$ is its standard deviation. Its value is bound between 0.5 and 1.5 , and takes on

\footnotetext{
12 The time subscript is omitted from now on to simplify the notation.

${ }^{13}$ The use of the logistic distribution controls for the effect of outliers.
} 
values larger (smaller) than 1.0 when individuals are more (less) experienced than those with the average person with the same level of education.

We would prefer to add more observable components to our skill index, but our data does not include other continuous measures of worker human capital quality. As a result, there may be increased importance on the final factor in equation (A.1), $a_{i, t}$ unobservable , measuring an individual's unobserved skills. Estimation of each individual's unobserved skill is implemented with a two high-dimensional fixedeffects wage equation using the procedure described in Guimarães and Portugal (2010) to capture unobserved productivity, and based on all the history we have for each individual in the labor market. The dependent variable is the log of the real hourly earnings. ${ }^{14}$ This wage equation controlled for individual age (and its square), job tenure (and its square), education, qualifications, year dummies, and, following Abowd et al. (1999), both worker and firm fixed effects (which are often used as proxies for worker and firm unobserved quality). This estimation allows us to estimate the worker-specific effect $\left(F E_{i}\right)$, which was then introduced in the final correction factor of the skill index, computed as follows:

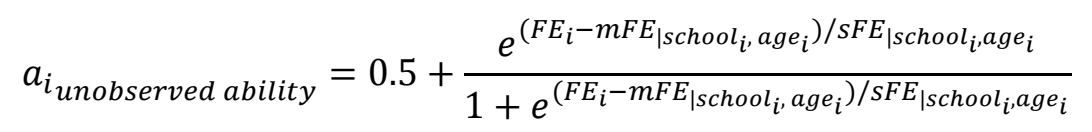

where $m F E_{\mid s c h o o l}$, age $_{i}$ denotes the average of worker fixed effects for individuals with the same schooling and age, and $s F E_{\mid s c h o o l_{i}, a_{i} e_{i}}$ is the standard deviation of those effects. Consequently, we now have a skill measure that allows two individuals with the same education level and age to be treated as potentially different in terms of skills, as long as their unobserved permanent skills are different. ${ }^{15}$

\footnotetext{
${ }^{14}$ Hourly earnings correspond to the ratio between total regular payroll (base wages and regular benefits) and the total number of normal hours worked in the reference period. Earnings were deflated using the Consumer Price Index. Outliers (i.e., the $1 \%$ with highest and lowest real hourly log earnings in each year) were removed from the estimations.

${ }^{15}$ As an illustration of the advantage of this multi-dimensional skill index over simpler measures based on schooling years only, we analyzed the distribution of both skill measures for both workers and entrepreneurs. The median entrepreneur in our sample had six years of formal education, being quite similar to the median worker employed at entry. However, the skill index for the median entrepreneur and the median worker is 6.63 and 5.44, respectively, with the difference being statistically significant at the $1 \%$ level, in line with the widespread literature documenting that entrepreneurs are more skilled than wage workers, on average. With this skill measure we are, thus, able to control for a greater heterogeneity at the individual-level.
} 


\section{APPENDIX B}

\section{Estimating Founder-Specific Human Capital Benchmarks}

To estimate human capital quality and quantity benchmarks, we use data on all 194,357 active firms with complete information in the $Q P$ during the period 1992-2007. The decision to include all firms, and not just firms in their founding years, was made to account for competitive effects in human capital decisions. Incumbent firms are important to include because they have endured various trials and the effects of competition, and benchmarks will reflect these effects.

We estimate time-specific and founder-specific benchmarks with the following system of equations:

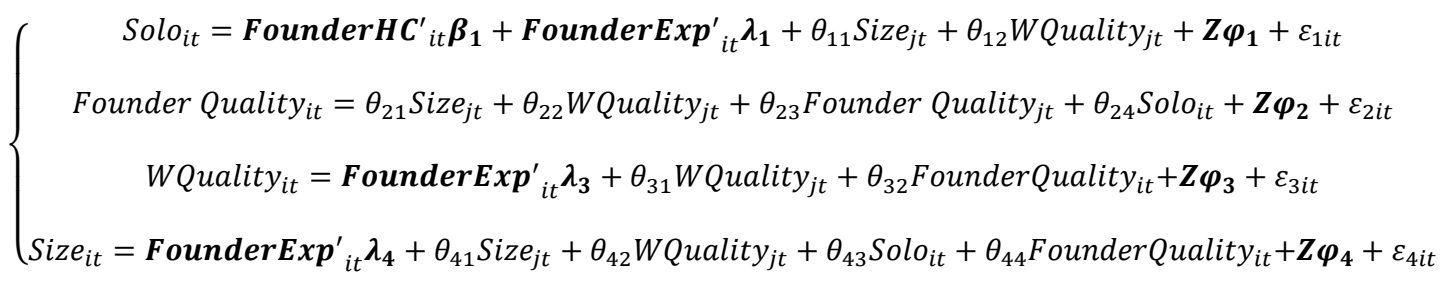

Dependent variables include, for each year $t$ and founder $i$, the dummy variable Solo coded "1" if the founder started the venture alone, and "0" otherwise; Founder Quality measuring the venture's average founder skill level; WQuality measuring the venture's average worker skill level; and Size measuring the venture's number of employees excluding the founder(s).

All equations include a vector $Z$, which contains dummy variables for firm age, year, 2-digit industry, Nuts III region, and variables distinguishing opportunity and necessity-driven startups. Because our data contains additional measures of founder human capital, we include them: FounderHC is a vector of variables including founder's age and education level (years of schooling), as measures of more general human capital, while FounderExp contains measures of specific human capital of the founder(s), namely their experience as entrepreneurs, in the industry, and in management positions. All these dimensions of specific human capital are measured in years. 
The specific structure of the recursive elements in the system of equations was motivated by recent empirical evidence showing that entrepreneurs' decision of having partners is not exogenous, but potentially driven by their preferences, psychological traits, ability, and experience (e.g., Cooper and Saral, 2013). The choice between running a business alone and sharing the ownership with other(s) may, in turn, have implications for the overall quality level of the entrepreneurial team, particularly if team members are strategically chosen in order to benefit from several kinds of complementarities, including skill complementarities (Ucbasaran et al., 2003; Forbes et al., 2006). Entrepreneurs' quality is then allowed to affect the choices of workforce average quality and workforce size, in line with the literature showing that more skilled entrepreneurs tend to hire more skilled workers (Garicano and Hubard, 2005; Baptista et al., 2013) and enter at a larger scale (Colombo et al., 2004; Coad et al, 2014).

The first equation in the system corresponds to the decision of entering (or staying in) the business alone or in a team. We expect this choice to be closely related to the founder general and specific human capital (measured by a set of variables in vectors FounderHC and FounderExp), as well as to the size and quality of the workforce to be employed. However, as these two last variables refer to endogenous choices in the system, and the equations must be designed recursively, we use the average size and the average quality level of the workers employed by firms operating in the same industry $j$ and year $t\left(\right.$ Size $_{j t}$ and $W$ Quality ${ }_{j t}$, respectively) as exogenous proxies for the quantity and quality of HR to be hired by the firm.

Implicit in the second equation is a strong association between entrepreneurs' quality and the characteristics of the workers to be hired. Again, as these variables cannot be introduced yet as independent variables, we include the average size and skill level of the workers employed by closer competitors (i.e., firms operating in the same industry, in the same year) as proxies. To consider that business owners might want - or need - to be as skilled as rivals, we include the average quality of a reference group of entrepreneurs (those in the same industry, in the same year).

The final two equations in the system above correspond to the key human capital choices of interest: the quality and quantity of workers to hire. These choices are expected to be influenced by the 
average choices of naturally comparable firms (competitors from the same industry), and also by the quality of the entrepreneur(s) making the hiring decisions. Appendix Table 1 summarizes the results from this simultaneous estimation.

\section{[Insert Appendix Table 1]}

The estimation results suggest that older, more educated, and more experienced individuals (both in the industry and in management positions) tend to be more prone to start a business alone. In contrast, more entrepreneurial experience is negatively associated with the probability of entering alone, maybe because those who were entrepreneurs in the past are more aware of the risks of founding a startup alone.

The results obtained for the second equation confirm that the level of skills exhibited by business owners is significantly and positively related to their decision of running the firm alone. It suggests that those who enter in teams are less skilled on average, so the decision of sharing the ownership with others may be strategic and aim to compensate the possible lack of skills of the individuals engaging in new venture creation. As expected, entrepreneurs' quality is also positively aligned with the average quality level of comparable business owners operating in the same industry.

Finally, the results confirm the existence of a strong and positive relation between worker and founder quality (third equation). More skilled and more experienced founders seem to hire more skilled workers and larger workforces on average (fourth equation). Moreover, the quantity (quality) of workers hired over firms' lifecycle is found to be significantly and positively associated with the average quantity (quality) of workers employed by competitors in the same industry. 
Appendix Table 1. Recursive mixed-process model for entrepreneurs' key HR decisions (All firms, entrants and incumbents, 1992-2007, Portugal)

\begin{tabular}{|c|c|c|c|c|}
\hline & $\begin{array}{l}\text { Solo } \\
\text { entrepreneur }\end{array}$ & $\begin{array}{l}\text { Founders' } \\
\text { quality }\end{array}$ & $\begin{array}{l}\text { Workers' } \\
\text { quality }\end{array}$ & $\begin{array}{l}\text { Workforce } \\
\text { size }\end{array}$ \\
\hline \multirow[t]{2}{*}{ Founders' age } & $0.0309 * * *$ & & & \\
\hline & $(0.0001)$ & & & \\
\hline \multirow[t]{2}{*}{ Founders' education } & $0.1058 * * *$ & & & \\
\hline & $(0.0003)$ & & & \\
\hline \multirow[t]{2}{*}{ Founders' industry-specific (2d) experience } & $0.0036^{* * * *}$ & & $0.0087 * * *$ & $0.0997 * * *$ \\
\hline & $(0.0005)$ & & $(0.0012)$ & $(0.0095)$ \\
\hline \multirow[t]{2}{*}{ Founders' entrepreneurial experience } & $-0.0100 * * *$ & & $0.0285^{* * *}$ & $0.3396^{* * *}$ \\
\hline & $(0.0009)$ & & $(0.0021)$ & $(0.0179)$ \\
\hline \multirow[t]{2}{*}{ Founders' experience in management positions } & $0.0451 * * *$ & & $0.0055^{* *}$ & $0.1984 * * *$ \\
\hline & $(0.0010)$ & & $(0.0023)$ & $(0.0191)$ \\
\hline \multirow[t]{2}{*}{ Average firm size in the same industry (2d) } & -0.0025 & 0.0152 & & $1.0239 * * *$ \\
\hline & $(0.0036)$ & $(0.0108)$ & & $(0.0499)$ \\
\hline \multirow[t]{2}{*}{ Average workers' quality in the same industry (2d) } & 0.0056 & $0.1523 * * *$ & $0.6816^{* * *}$ & $-0.6233 * *$ \\
\hline & $(0.0155)$ & $(0.0544)$ & $(0.0269)$ & $(0.3054)$ \\
\hline \multirow[t]{2}{*}{ Average founders' quality in the same industry (2d) } & & $0.6676^{* * *}$ & & \\
\hline & & $(0.0299)$ & & \\
\hline \multirow[t]{2}{*}{ Solo entrepreneur } & & $4.8718^{* * *}$ & & -1.9219 \\
\hline & & $(0.0096)$ & & $(1.4048)$ \\
\hline \multirow[t]{2}{*}{ Founders' quality } & & & $0.2692 * * *$ & $0.4968 *$ \\
\hline & & & $(0.0022)$ & $(0.2874)$ \\
\hline Year dummies & Yes & Yes & Yes & Yes \\
\hline Firm age dummies & Yes & Yes & Yes & Yes \\
\hline Industry (2d) dummies & Yes & Yes & Yes & Yes \\
\hline Region (Nuts III) dummies & Yes & Yes & Yes & Yes \\
\hline Type of firm (Necessity/Opportunity/Other) dummies & Yes & Yes & Yes & Yes \\
\hline Number of observations & \multicolumn{4}{|c|}{488,302} \\
\hline Log likelihood & \multicolumn{4}{|c|}{$-4,457.320$} \\
\hline
\end{tabular}




\section{REFERENCES}

Abowd, J. M., Kramarz, F., Margolis, D. 1999. High wage workers and high wage firms, Econometrica, 67(2), 251-334.

Agarwal, R., Audretsch, D. B. 2001. Does entry size matter? The impact of the life cycle and technology on firm survival, The Journal of Industrial Economics, 49(1), 21-43.

Audretsch, D. B., Mahmood, T. 1994. Firm selection and industry evolution: the post-entry performance of new firms, Journal of Evolutionary Economics, 4(3), 243-260.

Audretsch, D. B., Santarelli, E., Vivarelli, M. 1999. Start-up size and industrial dynamics: some evidence from Italian manufacturing, International Journal of Industrial Organization, 17(7), 965-983.

Baptista, R., Lima, F., Preto, M. T. 2013. Entrepreneurial skills and workers' wages in small firms, Small Business Economics, 40(2), 309-323.

Bates, T. 1990. Entrepreneur human capital inputs and small business longevity, The Review of Economics and Statistics, 72(4), 551-559.

Brüderl, J., Preisendörfer, P., Ziegler, R. 1992. Survival chances of newly founded business organizations, American Sociological Review, 57(2), 227-242.

Brüderl, J., Schussler, R. 1990. Organizational mortality: The liability of newness and adolescence, Administrative Science Quarterly, 35(3): 530-547.

Cabral, L., Mata, J. 2003. On the evolution of the firm size distribution: facts an theory, The American Economic Review, 93(4), 1075-1090.

Coad, A., Frankish, J. S., Nightingale, P., Roberts, R. G. 2014. Business experience and start-up size: Buying more lottery tickets next time around?, Small Business Economics, 43(3), 529-547.

Coff, R. 1997. Human assets and management dilemmas: Coping with hazards on the road to resourcebased theory, Academy of Management Review, 22(2), 374-402.

Colombo, M. G., Grilli, L. 2005. Founders' human capital and the growth of new technology-based firms: A competence-based view, Research Policy, 34(6), 796-816.

Colombo, M. G., Delmastro, M., Grilli, L. 2004. Entrepreneurs' human capital and the startup size of new technology-based firms, International Journal of Industrial Organization, 22(8-9), 1183-1211.

Cooper, A. C., Gimeno-Gascon, F. J., Woo, C. Y. 1994. Initial human and financial capital as predictors of new venture performance, Journal of Business Venturing, 9(5), 371-395.

Cooper, A. C., Saral, K. J. 2013. Entrepreneurship and team participation: An experimental study, European Economic Review, 59(2), 126-140.

Delmar, F., McKelvie, A.,Wennberg, K. 2013. Untangling the relationships among growth, profitability and survival in new firms, Technovation, 33(8-9), 276-291. 
Delmar, F., Shane, S. 2006. Does experience matter? The effect of founding team experience on the survival and sales of newly founded ventures, Strategic Organization, 4(3), 215-247.

Eisenhardt, K.M., Schoonhoven, C.B. 1990. Organizational growth: Linking founding team, strategy, environment and growth among U.S. semiconductor ventures, 1978-1988, Administrative Science Quarterly, 35(3): 504-529.

Forbes, D. P., Borchert, P. S., Zellmer-Bruhn, M. E., Sapienza, H. J. 2006. Entrepreneurial team formation: An exploration of new member addition, Entrepreneurship Theory \& Practice, 30(2), 225-248.

Garicano, L., Hubbard, T. N. 2005. Hierarchical sorting and learning costs: Theory and evidence from the law, Journal of Economic Behavior \& Organization, 58(2), 349-369.

Geroski, P. A., Mata, J., Portugal, P. 2010. Founding conditions and the survival of new firms, Strategic Management Journal, 31(5), 510-529.

Guimarães, P., Portugal, P. 2010. A simple feasible alternative procedure to estimate models with highdimensional fixed effects, The Stata Journal, 10(4), 628-649.

Haltiwanger, J. C., Lane, J. I., Spletzer, J. R. 1999. Productivity differences across employers: The roles of employer size, age, and human capital, The American Economic Review, 89(2), 94-98.

Haltiwanger, J. C., Lane, J. I., Spletzer, J. R. 2007. Wages, productivity and the dynamic interaction of businesses and workers, Labour Economics, 14(3), 575-602.

Huber, P., Oberhofer, H., Pfaffermayry, M. 2014. Job creation and the intra-distribution dynamics of the firm size distribution, Industrial and Corporate Change, 23(1), 171-197.

Hvide, H. K., Møen, J. 2010. Lean and hungry or fat and content? Entrepreneurs' wealth and startup performance, Management Science, 56(8), 1242-1258.

Ilmakunnas, P., Maliranta, M., Vainioma, J. 2004. The roles of employer and employee characteristics for plant productivity, Journal of Productivity Analysis, 21(3), 249-276.

Iranzo, S., Shivardi, F., Tosetti, E. 2008. Skill dispersion and firm productivity: An analysis with employer-employee matched data, Journal of Labor Economics, 26(2), 247-285.

Koch, A., Späth, J., Strotmann, H. 2013. The role of employees for post-entry firm growth, Small Business Economics, 41(3), 733-755.

Lancaster, T. 1990. The Econometric Analysis of Transition Data, Econometric Society Monographs, 17, Cambridge University Press.

Martins, P. 2008. Dispersion in wage premiums and firm performance, Economics Letters, 101(1), 63-65.

Mata, J., Machado, J. A. F. 1996. Firm startup size: A conditional quantile approach, European Economic Review, 40(6), 1305-1323.

Mata, J., Portugal, P. 1994. Life duration of new firms, The Journal of Industrial Economics, 42(3), 227245. 
Mata, J., Portugal, P. 2002. The survival of new domestic and foreign-owned firms, Strategic Management Journal, 23(4), 323-343.

Mellilo, F., Folta, TB., Delmar, F. 2012. Endogeneity in start-up size: Selection effects among types of entrants, Academy of Management Best Paper Proceedings.

Portela, M. 2001. Measuring skill: a multi-dimensional index, Economics Letters, 72(1), 27-32.

Rocha, V., Carneiro, A., Varum, C. 2015. Entry and exit dynamics of nascent business owners, Small Business Economics, 45(1), 63-84.

Roodman, D. 2011. Fitting fully observed recursive mixed-process models with cmp, The Stata Journal, 11(2), 159-206.

Sá, C., Florax, R. J. G. M., Rietveld, P. 2004. Determinants of the regional demand for higher education in The Netherlands: A gravity model approach, Regional Studies, 38(4), 375-392.

Sá, C., Florax, R. J. G. M., Rietveld, P. 2012. Living arrangement and university choice of Dutch prospective students, Regional Studies, 46(5), 651-667.

Shane, S., Stuart, T. 2002. Organizational endowments and the performance of university start-ups, Management Science, 48(1): 154-170.

Stinchcombe, A. L. 1965. Social structure and organizations. In J. G. March (Ed.), Handbook of Organizations, pp. 142-193. Chicago: Rand McNally.

Ucbasaran, D., Lockett, A., Wright, M., Westhead, P. 2003. Entrepreneurial founder teams: factors associated with member entry and exit, Entrepreneurship Theory \& Practice, 28(2), 107-128. 
Figure 1. Deviations of Initial Human Capital from Benchmarks From Founding Until Five Years After Founding

Panel A: Size Deviation ${ }^{\mathrm{a}}$

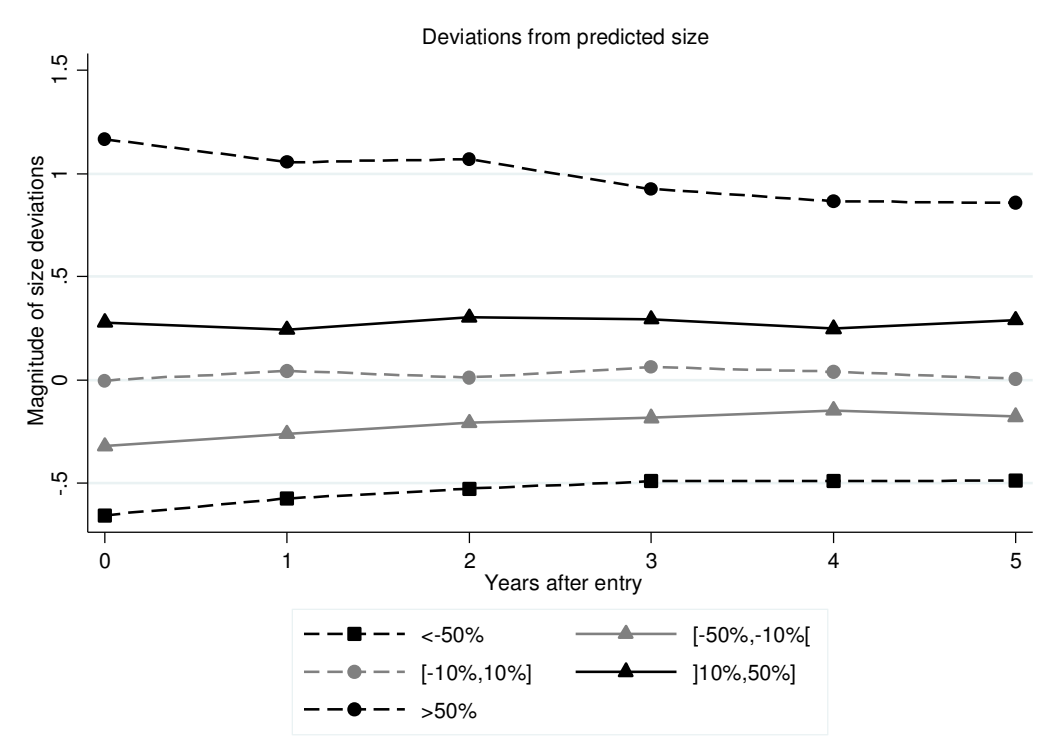

${ }^{a}$ Size deviations $s_{t}=\left(\right.$ firm size $_{t}-$ size benchmark $\left.{ }_{t}\right) /$ size benchmark $_{t}$ Calculations completed for ventures that survived at least five years. Benchmarks are time varying, as reported in Appendix A.
Panel B: Workforce Skill Deviation ${ }^{\mathrm{b}}$

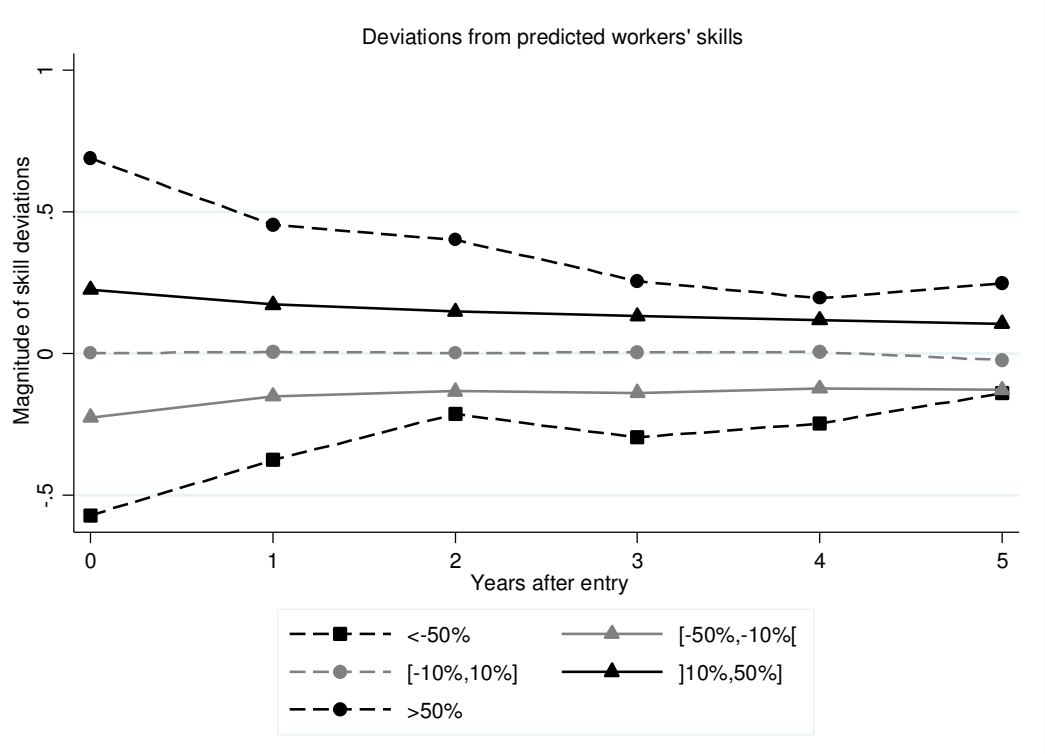

${ }^{\mathrm{b}}$ Workers' skill deviations $\mathrm{s}_{\mathrm{t}}=\left(\right.$ initial workforce quality $\mathrm{t}_{\mathrm{t}}$-benchmark workforce quality $\left.\mathrm{t}_{\mathrm{t}}\right) /$ benchmark workforce quality. Calculations completed for ventures that survived at least five years. Benchmarks are time varying, as reported in Appendix A. 
Table 1. Descriptive statistics for initial human capital quality and quantity

\begin{tabular}{|c|c|c|c|c|c|}
\hline & (1) & $(2)$ & (3) & (4) & (5) \\
\hline & Mean & SD & $\begin{array}{l}\text { Mean if } \\
\text { Survived }\end{array}$ & $\begin{array}{l}\text { Mean if } \\
\text { Failed }\end{array}$ & $\begin{array}{l}\text { Difference } \\
\text { (t-test): } \\
(3)-(4)\end{array}$ \\
\hline Initial workforce size (nr of employees) & 6.793 & 6.631 & 6.927 & 6.659 & $0.268 *$ \\
\hline Initial workforce quality (average skill index) & 5.657 & 1.619 & 5.871 & 5.440 & $0.4303 * * *$ \\
\hline Deviations from benchmark workforce size $(\%)$ & -0.331 & 0.015 & -0.285 & -0.378 & $0.093 * * *$ \\
\hline Deviations from benchmark workforce quality (\%) & -0.002 & 0.003 & 0.002 & -0.006 & 0.008 \\
\hline Number of Firms & 5,341 & 5,341 & 2,688 & 2,653 & \\
\hline
\end{tabular}

$* * *, * *$, and $*$ mean significant at $1 \%, 5 \%$, and $10 \%$ levels, respectively. Deviations from the benchmarks are measured in percentages and are computed as follows: $\underline{\text { (observed size or skills - predicted size or skills) }}$ predicted size or skills 
Table 2. Proportional hazard models estimating the hazard of firm closure

\begin{tabular}{|c|c|c|c|c|c|c|c|c|c|c|}
\hline & (1) & (2) & (3) & (4) & (5) & (6) & (7) & $(8)$ & Opportunity & Necessity \\
\hline Founders' quality level & $\begin{array}{l}-0.3461 * * * \\
(0.0425)\end{array}$ & $\begin{array}{l}-0.2738 * * * \\
(0.0434)\end{array}$ & $\begin{array}{l}-0.2015 \text { *** } \\
(0.0461)\end{array}$ & $\begin{array}{l}-0.2101 * * * \\
(0.0474)\end{array}$ & $\begin{array}{l}-0.1917 * * \\
(0.0876)\end{array}$ & $\begin{array}{l}-0.2880 * * * \\
(0.0487)\end{array}$ & $\begin{array}{l}-0.2701 * * \\
(0.1106)\end{array}$ & $\begin{array}{l}-0.2937 * * \\
(0.1133)\end{array}$ & $\begin{array}{l}-0.1633 \\
(0.1495)\end{array}$ & $\begin{array}{l}-0.4268 * * \\
(0.1764)\end{array}$ \\
\hline Founders' industry experience & $\begin{array}{l}-0.0109^{* *} \\
(0.0047)\end{array}$ & $\begin{array}{l}-0.0088^{*} \\
(0.0047)\end{array}$ & $\begin{array}{l}-0.0096^{* *} \\
(0.0047)\end{array}$ & $\begin{array}{l}-0.0102 * * \\
(0.0047)\end{array}$ & $\begin{array}{l}-0.0101 * * \\
(0.0048)\end{array}$ & $\begin{array}{l}-0.0153^{* * *} \\
(0.0048)\end{array}$ & $\begin{array}{l}-0.0159 * * * \\
(0.0048)\end{array}$ & $\begin{array}{l}-0.0156^{* * *} \\
(0.0049)\end{array}$ & $\begin{array}{l}-0.0034 \\
(0.0063)\end{array}$ & $\begin{array}{l}-0.0313^{* * *} \\
(0.0077)\end{array}$ \\
\hline Founders' entrepreneurial experience & $\begin{array}{l}-0.0029 \\
(0.0159)\end{array}$ & $\begin{array}{l}0.0093 \\
(0.0158)\end{array}$ & $\begin{array}{l}0.0086 \\
(0.0158)\end{array}$ & $\begin{array}{l}0.0074 \\
(0.0159)\end{array}$ & $\begin{array}{l}0.0077 \\
(0.0159)\end{array}$ & $\begin{array}{l}-0.0006 \\
(0.0159)\end{array}$ & $\begin{array}{l}0.0000 \\
(0.0161)\end{array}$ & $\begin{array}{l}0.0000 \\
(0.0161)\end{array}$ & $\begin{array}{l}-0.0071 \\
(0.0220)\end{array}$ & $\begin{array}{l}0.0026 \\
(0.0244)\end{array}$ \\
\hline Founders' management experience & $\begin{array}{l}-0.0307 * \\
(0.0164)\end{array}$ & $\begin{array}{l}-0.0259 \\
(0.0163)\end{array}$ & $\begin{array}{l}-0.0234 \\
(0.0163)\end{array}$ & $\begin{array}{l}-0.0232 \\
(0.0163)\end{array}$ & $\begin{array}{l}-0.0230 \\
(0.0163)\end{array}$ & $\begin{array}{l}-0.0280 * \\
(0.0163)\end{array}$ & $\begin{array}{l}-0.0278^{*} \\
(0.0163)\end{array}$ & $\begin{array}{l}-0.0283 * \\
(0.0164)\end{array}$ & $\begin{array}{l}-0.0868^{* * *} \\
(0.0230)\end{array}$ & $\begin{array}{l}0.0340 \\
(0.0238)\end{array}$ \\
\hline Single founder (vs team) & $\begin{array}{l}0.9973 * * * \\
(0.0347)\end{array}$ & $\begin{array}{l}0.9130 * * * \\
(0.0360)\end{array}$ & $\begin{array}{l}0.9115^{* * *} \\
(0.0360)\end{array}$ & $\begin{array}{l}0.9195 * * * \\
(0.0374)\end{array}$ & $\begin{array}{l}0.9188 * * * \\
(0.0375)\end{array}$ & $\begin{array}{l}0.9583 * * * \\
(0.0379)\end{array}$ & $\begin{array}{l}0.9556^{* * *} \\
(0.0384)\end{array}$ & $\begin{array}{l}0.9536^{* * *} \\
(0.0383)\end{array}$ & $\begin{array}{l}0.8760^{* * *} \\
(0.0523)\end{array}$ & $\begin{array}{l}1.0192 * * * \\
(0.0568)\end{array}$ \\
\hline Startup initial size & & $\begin{array}{l}-0.1921 * * * \\
(0.0212)\end{array}$ & $\begin{array}{l}-0.1964 * * * \\
(0.0212)\end{array}$ & $\begin{array}{l}-0.1726 * * * \\
(0.0375)\end{array}$ & $\begin{array}{l}-0.1740^{* * * *} \\
(0.0379)\end{array}$ & $\begin{array}{l}0.0062 \\
(0.0472)\end{array}$ & $\begin{array}{l}-0.0083 \\
(0.0513)\end{array}$ & $\begin{array}{l}-0.0017 \\
(0.0518)\end{array}$ & $\begin{array}{l}0.0276 \\
(0.0667)\end{array}$ & $\begin{array}{l}-0.0582 \\
(0.0833)\end{array}$ \\
\hline Workforce quality initial level & & & $\begin{array}{l}-0.2606^{* * *} \\
(0.0571)\end{array}$ & $\begin{array}{l}-0.2592 * * * \\
(0.0572)\end{array}$ & $\begin{array}{l}-0.3073 \\
(0.2008)\end{array}$ & $\begin{array}{l}-0.2512 * * * \\
(0.0573)\end{array}$ & $\begin{array}{l}-0.2905 \\
(0.2548)\end{array}$ & $\begin{array}{l}-0.2396 \\
(0.2603)\end{array}$ & $\begin{array}{l}-0.3977 \\
(0.3393)\end{array}$ & $\begin{array}{l}-0.1346 \\
(0.4146)\end{array}$ \\
\hline Size deviation at entry (\%) & & & & $\begin{array}{l}-0.0333 \\
(0.0431)\end{array}$ & $\begin{array}{l}-0.0310 \\
(0.0440)\end{array}$ & & & & & \\
\hline Workforce quality deviation at entry (\%) & & & & & $\begin{array}{l}0.0520 \\
(0.2076)\end{array}$ & & & & & \\
\hline Size deviations at entry $<0 \%$ & & & & & & $\begin{array}{l}0.6255^{* * *} \\
(0.1026)\end{array}$ & $\begin{array}{l}0.6144 * * * \\
(0.1097)\end{array}$ & $\begin{array}{l}0.6237 * * * \\
(0.1101)\end{array}$ & $\begin{array}{l}0.7692 * * * \\
(0.1439)\end{array}$ & $\begin{array}{l}0.4253 * * \\
(0.1744)\end{array}$ \\
\hline Size deviations at entry $>0 \%$ & & & & & & $\begin{array}{l}0.0759 * \\
(0.0450)\end{array}$ & $\begin{array}{l}0.0806^{*} \\
(0.0457)\end{array}$ & $\begin{array}{l}0.0779 * \\
(0.0458)\end{array}$ & $\begin{array}{l}0.1280 * * \\
(0.0608)\end{array}$ & $\begin{array}{l}0.0596 \\
(0.0708)\end{array}$ \\
\hline Workforce quality deviations at entry $<0 \%$ & & & & & & & $\begin{array}{l}-0.2608 \\
(0.3527)\end{array}$ & $\begin{array}{l}-0.1999 \\
(0.3584)\end{array}$ & $\begin{array}{l}-0.4141 \\
(0.4690)\end{array}$ & $\begin{array}{l}-0.0931 \\
(0.5647)\end{array}$ \\
\hline Workforce quality deviations at entry $>0 \%$ & & & & & & & $\begin{array}{l}-0.1671 \\
(0.2208)\end{array}$ & $\begin{array}{l}-0.2108 \\
(0.2256)\end{array}$ & $\begin{array}{l}-0.0796 \\
(0.2830)\end{array}$ & $\begin{array}{l}-0.3179 \\
(0.3908)\end{array}$ \\
\hline Necessity-driven entrepreneur & & & & & & & & $\begin{array}{l}-0.0282 \\
(0.0292)\end{array}$ & & \\
\hline Year dummies & Yes & Yes & Yes & Yes & Yes & Yes & Yes & Yes & Yes & Yes \\
\hline Firm age dummies & Yes & Yes & Yes & Yes & Yes & Yes & Yes & Yes & Yes & Yes \\
\hline Industry-level variables & Yes & Yes & Yes & Yes & Yes & Yes & Yes & Yes & Yes & Yes \\
\hline Business location & Yes & Yes & Yes & Yes & Yes & Yes & Yes & Yes & Yes & Yes \\
\hline Number of Observations & 17,381 & 17,381 & 17,381 & 17,381 & 17,381 & 17,381 & 17,381 & 17,381 & 9,820 & 7,561 \\
\hline Log Likelihood & $-9,580.4$ & $-9,538.2$ & $-9,527.9$ & $-9,527.6$ & $-9,527.5$ & $-9,506.8$ & $-9,504.5$ & $-9,504.1$ & $-5,504.7$ & $-3,965.8$ \\
\hline
\end{tabular}

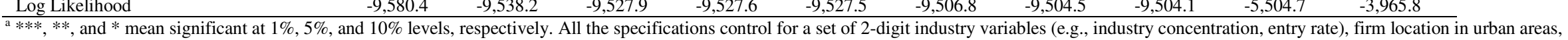
year dummies, firm age dummies, and a gamma-distributed firm-specific term to model unobserved heterogeneity at the firm-level. 
Table 3. Heckman estimates for second-stage firm-level employment growth rate

\begin{tabular}{|c|c|c|c|c|c|c|c|c|c|c|}
\hline & $(1)$ & $(2)$ & (3) & $(4)$ & $(5)$ & $(6)$ & $(7)$ & $(8)$ & Opportunity & Necessity \\
\hline \multirow[t]{2}{*}{ Founders' quality level } & $0.0219 * *$ & $0.0302 * * *$ & $0.0291 * * *$ & $0.0234^{* *}$ & $0.0858 * * *$ & $0.0293^{* *}$ & $0.1253^{* * * *}$ & $0.1117 * * *$ & $0.1251 * * *$ & $0.0994 * * *$ \\
\hline & $(0.0203)$ & $(0.0098)$ & $(0.0103)$ & $(0.0107)$ & $(0.0194)$ & $(0.0114)$ & $(0.0248)$ & $(0.0252)$ & $(0.0355)$ & $(0.0352)$ \\
\hline \multirow[t]{2}{*}{ Founders' industry experience } & $0.0039 * * *$ & $0.0040 * * *$ & $0.0040 * * *$ & $0.0036^{* * *}$ & $0.0040 * * *$ & $0.0039 * * *$ & $0.0046^{* * *} *$ & $0.0047 * * *$ & $0.0055^{* * *} *$ & $0.0034 * *$ \\
\hline & $(0.0011)$ & $(0.0010)$ & $(0.0010)$ & $(0.0010)$ & $(0.0010)$ & $(0.0011)$ & $(0.0011)$ & $(0.0011)$ & $(0.0014)$ & $(0.0015)$ \\
\hline \multirow[t]{2}{*}{ Founders' entrepreneurial experience } & $-0.0057^{*}$ & -0.0046 & -0.0046 & $-0.0053^{*}$ & -0.0043 & -0.0048 & -0.0030 & -0.0030 & -0.0020 & -0.0026 \\
\hline & $(0.0032)$ & $(0.0030)$ & $(0.0030)$ & $(0.0030)$ & $(0.0030)$ & $(0.0031)$ & $(0.0031)$ & $(0.0031)$ & $(0.0043)$ & $(0.0044)$ \\
\hline \multirow[t]{2}{*}{ Founders' management experience } & $0.0071 * *$ & $0.0078 * *$ & $0.0077 * *$ & $0.0075^{* *}$ & $0.0082 * * *$ & $0.0079 * *$ & $0.0092 * * *$ & $0.0088^{* * *}$ & $0.0083^{*}$ & $0.0077^{*}$ \\
\hline & $(0.0033)$ & $(0.0031)$ & $(0.0031)$ & $(0.0031)$ & $(0.0031)$ & $(0.0032)$ & $(0.0032)$ & $(0.0032)$ & $(0.0042)$ & $(0.0046)$ \\
\hline \multirow[t]{2}{*}{ Single founder (vs team) } & $-0.0192^{* *}$ & $-0.0248 * * *$ & $-0.0249 * * *$ & $-0.0196^{* *}$ & $-0.0208^{* *}$ & $-0.0235^{* * *}$ & $-0.0289 * * *$ & $-0.0276 * * *$ & $-0.0237 *$ & $-0.0247 * *$ \\
\hline & $(0.0081)$ & $(0.0077)$ & $(0.0077)$ & $(0.0081)$ & $(0.0081)$ & $(0.0086)$ & $(0.0087)$ & $(0.0087)$ & $(0.0122)$ & $(0.0116)$ \\
\hline \multirow[t]{2}{*}{ Startup initial size } & & $-0.0294 * * *$ & $-0.0293 * * *$ & $-0.0148 *$ & $-0.0186^{* *}$ & $-0.0256^{* *}$ & $-0.0420 * * *$ & $-0.0376^{* * * *}$ & $-0.0283^{*}$ & $-0.0482 * *$ \\
\hline & & $(0.0049)$ & $(0.0049)$ & $(0.0089)$ & $(0.0089)$ & $(0.0116)$ & $(0.0124)$ & $(0.0124)$ & $(0.0163)$ & $(0.0188)$ \\
\hline \multirow[t]{2}{*}{ Workforce quality initial level } & & & 0.0043 & 0.0051 & $-0.1618^{* * *}$ & 0.0051 & $-0.2391 * * *$ & $-0.2127 * * *$ & $-0.2726 * * *$ & $-0.1649 * *$ \\
\hline & & & $(0.0129)$ & $(0.0129)$ & $(0.0451)$ & $(0.0129)$ & $(0.0571)$ & $(0.0576)$ & $(0.0803)$ & $(0.0822)$ \\
\hline \multirow[t]{2}{*}{ Size deviation at entry $(\%)$} & & & & $-0.0178 *$ & -0.0120 & & & & & \\
\hline & & & & $(0.0091)$ & $(0.0092)$ & & & & & \\
\hline \multirow[t]{2}{*}{ Workforce quality deviation at entry (\%) } & & & & & $0.1794 * * *$ & & & & & \\
\hline & & & & & $(0.0465)$ & & & & & \\
\hline \multirow[t]{2}{*}{ Size deviations at entry $<0 \%$} & & & & & & -0.0152 & $-0.0498^{*}$ & -0.0416 & -0.0247 & -0.0586 \\
\hline & & & & & & $(0.0247)$ & $(0.0260)$ & $(0.0260)$ & $(0.0350)$ & $(0.0382)$ \\
\hline \multirow[t]{2}{*}{ Size deviations at entry $>0 \%$} & & & & & & $-0.0201 * *$ & -0.0125 & -0.0143 & -0.0127 & -0.0135 \\
\hline & & & & & & $(0.0094)$ & $(0.0096)$ & $(0.0095)$ & $(0.0129)$ & $(0.0139)$ \\
\hline \multirow[t]{2}{*}{ Workforce quality deviations at entry $<0 \%$} & & & & & & & $-0.3094 * * *$ & $-0.2766 * * *$ & $-0.3523 * * *$ & $-0.2261 * *$ \\
\hline & & & & & & & $(0.0795)$ & $(0.0800)$ & $(0.1106)$ & $(0.1146)$ \\
\hline \multirow[t]{2}{*}{ Workforce quality deviations at entry $>0 \%$} & & & & & & & $0.2189^{* * *}$ & $0.1967 * * *$ & $0.2569^{* * *}$ & $0.1256^{*}$ \\
\hline & & & & & & & $(0.0490)$ & $(0.0495)$ & $(0.0668)$ & $(0.0746)$ \\
\hline \multirow[t]{2}{*}{ Necessity-driven entrepreneur } & & & & & & & & $-0.0151 * *$ & & \\
\hline & & & & & & & & $(0.0064)$ & & \\
\hline \multirow[t]{2}{*}{ Inverse Mills' Ratio } & $0.4059 * * *$ & $0.3222 * * *$ & $0.3237 * * *$ & $0.3190 * * *$ & $0.3100 * * *$ & $0.3346^{* * *}$ & $0.3378 * * *$ & $0.3177 * * *$ & $0.2316^{* * *}$ & $0.3454 * * *$ \\
\hline & $(0.0490)$ & $(0.0484)$ & $(0.0486)$ & $(0.0487)$ & $(0.0485)$ & $(0.0499)$ & $(0.0500)$ & $(0.0503)$ & $(0.0695)$ & $(0.0638)$ \\
\hline Dummies for year, firm age, industry and location & Yes & Yes & Yes & Yes & Yes & Yes & Yes & & Yes & \\
\hline Number of Observations & 16,886 & 16,886 & 16,886 & 16,886 & 16,886 & 16,886 & 16,886 & 16,886 & 9,507 & 7,379 \\
\hline Number of Uncensored Observations & 15,305 & 15,305 & 15,305 & 15,305 & 15,305 & 15,305 & 15,305 & 15,305 & 8,543 & 6,763 \\
\hline Wald $\chi^{2}$ & 297.5 & 371.7 & 371.3 & 376.8 & 395.3 & 373.6 & 394.1 & 406.8 & 307.0 & 170.4 \\
\hline
\end{tabular}

***.**, \&* significant at $1 \%, 5 \%$, and $10 \%$ levels, respectively. Heckman two-step model, where $1^{\text {st }}$ stage is survival. The survival equation includes all the variables considered in Table 2 . The second stage

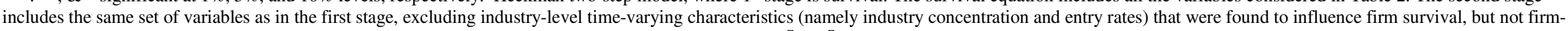
level employment growth. The dependent variable in the second stage is Employment Growth $h_{i, t+1}=\frac{E_{i t+1}-E_{i t}}{0.5 *\left(E_{i t+1}+E_{i t}\right)}$, where $E_{i t}$ represents total employment of firm i in year t. 